\title{
Pseudomonas spp. and $P$. fluorescens: population in refrigerated raw milk
}

\section{Kelly Molin de Almeida ${ }^{1}$ Samera Rafaela Bruzaroski ${ }^{2}$ Daniel Zanol ${ }^{2}$ Marcela de Melo $^{3}$ Joice Sifuentes dos Santos ${ }^{4}$ Lina Casale Aragon Alegro ${ }^{4}$ Bruno Garcia Botaro ${ }^{4}$ Elsa Helena Walter de Santana ${ }^{*}$}

\author{
${ }^{1}$ Universidade Norte do Paraná, UNOPAR, Londrina, PR, Brasil. \\ ${ }^{2}$ Curso de Medicina Veterinária, UNOPAR, Londrina, PR, Brasil. \\ ${ }^{3}$ Curso de Biomedicina, UNOPAR, Londrina, PR, Brasil. \\ ${ }^{4}$ Programa de Pós-graduação em Ciência e Tecnologia de Leite e Derivados, UNOPAR, Av. Paris, 675, 86041120, Londrina, PR, \\ Brasil. E-mail: elsahws@hotmail.com. "Corresponding author.
}

ABSTRACT: Raw milk samples were collected from cooling tanks (after they cooled for 48 h) in five dairy farms and the corresponding bulk tank (bulk milk transportation, BMT) when they arrived to the industry. Routine physical chemical analyzes and quantification of psychrotrophic (Pseudomonas spp. and P. fluorescens) and aerobic mesophilic (AM) populations were performed. Only relative density and titratable acidity values for samples of milk from three farms were in agreement to the quality parameters required by law. In the BMT, only the protein content has not reached the minimum value established by law, and counting was performed for AM (>10 $0^{5}$ colony forming units $\left.(\mathrm{CFU}) \mathrm{mL}^{-1}\right)$ and psychrotrophic bacteria $\left(2.8 \times 10^{6} \mathrm{CFU} \mathrm{mL}^{-1}\right)$. Pseudomonas spp. counting corresponded to $17.9 \%$ of the psychrotrophic population, and $P$. fluorescens was $3.4 \%$ of Pseudomonas spp. count. In milk samples from dairy farms, counts were variable for AM $\left(3.4 \times 10^{5}\right.$ to $\left.3.7 \times 10^{7} \mathrm{CFU} \mathrm{mL}^{-1}\right)$, psychrotrophic $\left(4.0 \times 10^{4}\right.$ to $\left.3.1 \times 10^{6} \mathrm{CFU} \mathrm{mL}^{-1}\right)$, Pseudomonas spp. $\left(2.3 \times 10^{4}\right.$ to $\left.1.8 \times 10^{5} \mathrm{CFU} \mathrm{mL}^{-1}\right)$, and P. fluorescens (62 to $8.4 \times 10^{3} \mathrm{CFU} \mathrm{mL}^{-1}$ ). For the populations studied, no statistical difference (P>0.05) was observed between counts reported in milk samples collected in dairy farms (cooling tanks) and BMT. Therefore, the genera Pseudomonas spp. and P. fluorescens were not the most frequent psychrotrophic bacteria in this studied milk transportation line.

Key words: psychrotrophic, quality, enzymes.

Pseudomonas spp. e $P$. fluorescens: população em leite cru refrigerado

RESUMO: Amostras de leite foram coletadas de tanques de refrigeração (após 48h de refrigeração) em cinco fazendas de produção $e$ do respectivo caminhão tanque (leite de conjunto, LC) ao chegar à indústria beneficiadora. Análises físico químicas de rotina e quantificação das populações de bactérias psicrotróficas (Pseudomonas spp. e P. fluorescens) e aeróbios mesófilos (AM) foram realizadas. Apenas os valores de densidade relativa e acidez titulável de amostras de leite de três fazendas estavam de acordo com a legislação. No LC, apenas o teor de proteína não atingiu o valor mínimo estabelecido por lei, e a contagem foi realizada para AM (>10 ${ }^{5}$ unidades formadoras de colonias (UFC) $\left.m L^{-1}\right)$ e psicrotróficos $\left(2,8 \times 10^{6} U F C \mathrm{~mL}^{-1}\right)$. A contagem de Pseudomonas spp. correspondeu a 17,9\% da população de psicrotróficos, e 3,4\% da contagem de Pseudomonas spp. eram da espécie P. fluorescens. Nas amostras de leite

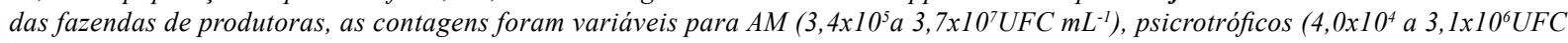

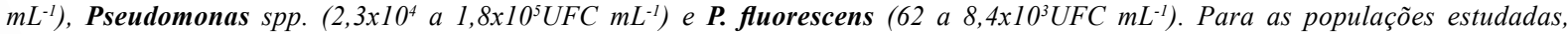
nenhuma diferença estatistica $(P>0,05)$ foi observada entre as contagens encontradas nas amostras de leite coletadas nas fazendas (tanques de resfriamento) e do LC. Portanto, o gênero Pseudomonas spp. e a espécie P. fluorescens não foram os psicrotróficos mais frequentes nesta linha de transporte de leite estudada.

Palavras-chave: psicrotrófico, qualidade, enzima.

\section{INTRODUCTION}

Guidelines for cooling milk in dairy farms and its transportation were established in Brazil in 2002 (BRASIL, 2002) as a response to international regulations and market demands. Since then, changes in milk chain production profile and qualitative advances in the regulation of total bacterial (TBC) and somatic cell (SCC) counts in raw milk have occurred (BRASIL, 2002), and the guidelines were updated in 2011 (BRASIL, 2011). Initially, the values for TBC and SCC should not exceed 600,000 colony forming units (CFU) $\mathrm{mL}^{-1}$ and 600,000 somatic cells (SC) $\mathrm{mL}^{-1}$, respectively. Later (July 1, 2014), these 
parameters were changed to $300,000 \mathrm{CFU} \mathrm{mL}^{-1}$ (TBC) and 500,000 cells $\mathrm{mL}^{-1}$ (SC) (BRASIL, 2011).

Both Ministry of Agriculture, Livestock, and Food Supply (MAPA) regulations determine that raw milk temperature at dairy farms must be $4^{\circ} \mathrm{C}$ or bellow. The temperatures must not exceed $7^{\circ} \mathrm{C}$ at dairy farm, when chilling is obtained by immersion of milk buckets or community bulk tanks, and this temperature must be reached within $3 \mathrm{~h}$ after milking of the dairy herd is complete. Milk temperature must be at or below $10^{\circ} \mathrm{C}$ when the container truck arrives at the dairy plant, and its maximum time at the farm must not exceed $48 \mathrm{~h}$ (BRASIL, 2002; BRASIL, 2011). However, storage of raw refrigerated milk with high TBC for periods longer than $48 \mathrm{~h}$ at dairy farm has negatively affected dairy products mainly due to an increase in the psychrotrophic bacterial population (SANTOS et al., 2009). Psychrotrophic bacteria are mostly Gram negative bacteria, which produced heat-resistant proteolytic and lipolytic enzymes (BRAMLEY A\& MCKINNON, 1996; MUIR, 1996; ANDRADE et al, 1998). Poor milking practices (VALLIN et al., 2009; YAMAZI et al., 2010; SILVA et al., 2011) and overall environmental contamination (YAMAZI et al., 2010; SILVA et al., 2011) heavily contributed to the increase in psychrotrophic species population in raw milk.

Pseudomonas spp. represents the most frequent deteriorating psychrotrophic microflora in refrigerated raw milk, and Pseudomonas fluorescens is the most frequently reported species (JAYARAO \& WANG, 1999; FAGUNDES et al., 2006; ARCURI et al., 2008; SANTOS et al., 2009). Due to the changes in the entire milk production in Brazil, verifying the impact of raw milk cooling at dairy farms on Pseudomonas spp. and $\boldsymbol{P}$. fluorescens behavior is necessary. The aim of this study was to quantitatively evaluate the presence of psychrotrophic Pseudomonas spp. and $\boldsymbol{P}$. fluorescens in refrigerated raw milk from different dairy farms, as well as the effect of bulk milk transportation on these populations.

\section{MATERIALS AND METHODS}

\section{Samples}

Milk samples were collected from Jun 2013 to Feb 2014. Two milk samples were taken from five (A, B, C, D, and E) dairy farms in Londrina (Paraná State, Brazil), in a total of ten milk samples from individual dairy farm cooling tanks. Bulk milk transporter took only milk from the farms included in the study directly to the dairy plant, where milk samples were collected before delivery. Samples were kept in styrofoam box with reusable ice packs and brought to the Microbiology Laboratory for immediate analysis. Route length between farms and dairy plant was about $70 \mathrm{~km}$. At the beginning of the study, each dairy producer was asked to complete a questionnaire on good farm and milking practices. A cooled and thoroughly homogenized milk sample $(600 \mathrm{~mL})$ was taken from each dairy farm with a sterilized recipient. A total of $1,200 \mathrm{~mL}$ of thoroughly homogenized milk sample was also taken directly from the bulk tank (six distinct 200-mL fractions) when the truck arrived at the plant. Milk temperature was recorded as indicated in the equipment.

\section{Physical and chemical analysis}

Protein content $(\%)$, fat content $(\%)$, nonfat solids (NFS) (\%), titratable acidity ( ${ }^{\circ}$ Dornic), density $\left(\mathrm{g} \mathrm{mL}^{-1}\right)$, and cryoscopy index $(\mathrm{CI})\left({ }^{\circ} \mathrm{H}\right)$ were determined according to the AOAC (1997). Analyses were performed in triplicate.

\section{Microbiological analysis}

Petrifilm ${ }^{\mathrm{TM}}$ AC (3M Brazil Ltda) was used as recommended by the manufacturer, but with modification (HOUGHTBY et al., 1992) to count aerobic mesophilic microorganisms. Psychrotrophic bacteria were counted by surface-plating in Plate Count Agar (Himedia, Mumbai, India) at $21^{\circ} \mathrm{C}$ for 25h (OLIVEIRA; PARMELLE, 1976). For Pseudomonas spp. counting, CFC-supplemented Pseudomonas Agar Base (Himedia, Mumbai, India) was used (FAGUNDES et al., 2006) at $30^{\circ} \mathrm{C}$ for $48 \mathrm{~h}$.

Tripticase in soy broth (TSB; Himedia, Mumbai, India) was used for $\boldsymbol{P}$. fluorescens counting: each milk sample $(2.5 \mathrm{~mL})$ was pre-incubated $\left(21^{\circ} \mathrm{C}\right.$; $18 \mathrm{~h})$ in media $(5 \mathrm{~mL})$. Then decimal dilutions were performed with the final broth, which was plated on the surface of Pseudomonas Cetrimide Agar medium (Oxoid, England) (SANTOS et al., 2009). After incubation $\left(21^{\circ} \mathrm{C} ; 48 \mathrm{~h}\right)$, only the greenishyellow colonies were counted under ultraviolet light (380nm) (KING, 1954). All microbiological results were expressed as $\mathrm{CFU} \mathrm{mL} \mathrm{m}^{-1}$ of milk. All analyses were performed in duplicate.

\section{Statistical analysis}

Physical-chemical and microbiological data were evaluated using analysis of variance (ANOVA) and Tukey's test $(\mathrm{P}<0.05$ and $\mathrm{P}<0.10)$ and the Statistica (STATSOFT, 2008) software. Results were presented as mean \pm standard deviation (SD), and milk samples from farm cooling tanks and bulk milk transportation throughout the study are compared. 


\section{RESULTS AND DISCUSSION}

A bulk cooling tank was used in every milk farm studied. Milking parlors had a roof and cemented floor. Farmers did not know the physical-chemical and microbiological characteristics of water used in the dairy parlors. Morning milking yields were invariably frozen in tanks of dairy farms B and $\mathrm{C}$, as the equipment were overestimated to accommodate their productions (Table 1).

Among the physical-chemical data evaluated in samples from the study farms throughout the sampling period, only milk titratable acidity (14$\left.18^{\circ} \mathrm{D}\right)$ and density $\left(1.028-1.034 \mathrm{~g} \mathrm{~mL}^{-1} ; 15^{\circ} \mathrm{C}\right.$,) met the minimum quality parameters as established by the Brazilian law on the subject (BRASIL, 2011) (Table 2). Some problems were reported at the milk dairy farm $\mathrm{C}$ where water addition was suspected, as indicated by the freezing point value $\left(-0.509^{\circ} \mathrm{H}\right)$ and decreased the NFS $(8.2 \%)$ and fat contents $(2.8 \%)$ (Table 2$)$. Presence of water in the cooling tank can be responsible for the changes observed in the milk freezing point.

Minimum values were established (BRASIL, $2011)$ for crude protein $(2.9 \%)$, fat (3\%), NFS $(8.4 \%)$, density $\left(1.028-1.034 \mathrm{~g} \mathrm{~mL}^{-1}\right)$, and freezing point index (from -0.530 to $-0.550^{\circ} \mathrm{H}$ ). Water addition to milk changes its freezing point, making it approach to that of water $\left(0^{\circ} \mathrm{C}\right)$ due to dilution of milk components, especially lactose and chlorides (WALSTRA et al., 2006). Physical-chemical values for the BMT samples were within the parameters required by the Brazilian law, but the protein content was below the minimum required $(2.9 \%)$. A decreased protein content was also observed among milk samples from the other dairy farms (Table 2). Although cow's nutrition was not evaluated, the protein index could be related to both the low quality of pastures and decreased dry matter in animals feeding (MARTINS et al., 2006).

Average mesophilic bacteria count were in the range $3.4 \times 10^{5}$ to $3.7 \times 10^{6} \mathrm{CFU} \mathrm{mL}^{-1}$, with no significant difference $(\mathrm{P}>0.05)$ between the individual populations reported in milk samples from dairy farm cooling milk tanks and the corresponding BMT (Table 3 ). Within the study period, only dairy farms that followed the good practices, had TBC meeting the microbiological parameters established by the federal regulation $\left(6.0 \times 10^{5} \mathrm{CFU} \mathrm{mL}^{-1}\right)$, (Table 1). However, TBC regulation was redefined on July 1, 2014 (3.0x10 $0^{5} \mathrm{CFU} \mathrm{mL} \mathrm{mL}^{-1}$; BRASIL, 2011), and thus milk dairy farm $\mathrm{E}$ became close to the TBC cut-off limit, given the average count of mesophilic bacteria throughout the sampling period of this study (Table 3). Table 3 also shows that the BMT

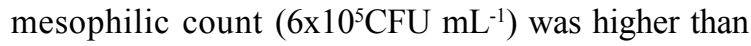
the minimum value established by the Brazilian milk quality regulation during the studied period, as well as the current milk quality parameters (BRASIL, 2011). In general, milk produced in Brazil has low quality, as it contains high bacteria and somatic cell counts due to both poor hygiene practices during milking and inadequate sanitation (MARTINS et al., 2008; CATANIO et al., 2012; RIBEIRO JUNIOR et al., 2015). Psychrotrophic average count in milk from study dairy farms ranged from $4.0 \times 10^{5}$ to $3.1 \times 10^{7} \mathrm{CFU}$ $\mathrm{mL}^{-1}$ (Table 3). Milk dairy farm E (Table 1) showed the lowest psychrotrophic count, which was different $(\mathrm{P}<0.05)$ from that of BMT. Surely, these results are due

Table 1 - Production characteristics and main milking practices in five milk farms (A, B, C, D, and E) in the Londrina region, Paraná State, Brazil, from June 2013 to February 2014.

\begin{tabular}{|c|c|c|c|c|c|}
\hline \multirow{2}{*}{ Characteristics } & \multicolumn{5}{|c|}{ - } \\
\hline & A & $\mathrm{B}$ & $\mathrm{C}$ & $\mathrm{D}$ & $\mathrm{E}$ \\
\hline Production $\left(\mathrm{L} \mathrm{day}^{-1}\right)$ & 208 & 450 & 550 & 450 & 2000 \\
\hline Water sources & Water mine & Water mine & Artesian well & Artesian well & Water mine \\
\hline Chlorinated water & $\mathrm{N}^{*}$ & $\mathrm{~N}$ & $\mathrm{~N}$ & $\mathrm{~N}$ & $\mathrm{Y}^{*}$ \\
\hline Milking System & Mechanical CS ${ }^{* *}$ & Mechanical $\mathrm{CS}^{* *}$ & Mechanical CS $^{* *}$ & Mechanical CS ${ }^{* *}$ & Mechanical S $^{* *}$ \\
\hline Water leftover in the cooling tank & $\mathrm{N}$ & $\mathrm{Y}$ & $\mathrm{Y}$ & $\mathrm{N}$ & $\mathrm{N}$ \\
\hline Use of strip cup & $\mathrm{N}^{* * *}$ & Yes & $\mathrm{N}^{* * *}$ & $\mathrm{Y}$ & $\mathrm{Y}$ \\
\hline Use of CMT ${ }^{* * * *}$ & $\mathrm{~N}^{* * *}$ & $\mathrm{~N}$ & $\mathrm{~N}^{* * *}$ & $\mathrm{Y}$ & $\mathrm{Y}$ \\
\hline Use of predip & $\mathrm{Y}$ & $\mathrm{Y}$ & $\mathrm{N}$ & $\mathrm{N}$ & $\mathrm{Y}$ \\
\hline Teats dried with paper towels & $\mathrm{Y}$ & $\mathrm{Y}$ & $\mathrm{Y}$ & $\mathrm{Y}$ & $\mathrm{Y}$ \\
\hline Use of postdip & $\mathrm{N}$ & $\mathrm{N}$ & $\mathrm{N}$ & $\mathrm{Y}$ & $\mathrm{Y}$ \\
\hline
\end{tabular}

${ }^{*} \mathrm{Y}=\mathrm{Yes} ; \mathrm{N}=\mathrm{No} ;{ }^{*} \mathrm{CS}=\mathrm{Closed}$ system; ${ }^{* * *}$ test is performed only when a problem is noticed; ${ }^{* * *} \mathrm{CMT}=\mathrm{California}$ mastitis test. 
Table 2 - Physical and chemical measurements (mean values) ${ }^{*}$ of raw milk refrigerated samples collected from individual cooling tanks at five milk farms (A, B, C, D, and E) and the corresponding bulk milk transportation (BMT) trucks before delivery to a dairy industry in the Londrina region, Paraná State, Brazil, from June 2013 to February 2014.

\begin{tabular}{|c|c|c|c|c|c|c|}
\hline Milk farms & Protein $(\%)$ & Fat $(\%)$ & $\operatorname{NFS}^{C}(\%)$ & Acidity ( $\left.{ }^{\circ} \mathrm{D}\right)$ & $\operatorname{Density}^{* * *}\left(\mathrm{~g} \mathrm{~mL}^{-1}\right)$ & Cryoscopy index $\left.{ }^{\circ} \mathrm{H}\right)$ \\
\hline A & 2.7 & $4.1^{\mathrm{a}}$ & $8.6^{\mathrm{a}}$ & $14.7^{\mathrm{b}}$ & $1.030^{\mathrm{A} . \mathrm{B}}$ & $-0.537^{b}$ \\
\hline B & 2.8 & $3.5^{\mathrm{b}}$ & $8.5^{\mathrm{a}, \mathrm{b}}$ & $16.5^{\mathrm{a}}$ & $1.030^{\mathrm{A}, \mathrm{B}}$ & $-0.546^{\mathrm{a}}$ \\
\hline $\mathrm{C}$ & 2.6 & $2.8^{\mathrm{c}}$ & $8.2^{\mathrm{c}}$ & $16.28^{\mathrm{a}}$ & $1.029^{\mathrm{B}}$ & $-0.509^{c}$ \\
\hline $\mathrm{D}$ & 2.8 & $3.3^{\mathrm{b}}$ & $8.3^{\mathrm{b}, \mathrm{c}}$ & $15.7^{\mathrm{a}, \mathrm{b}}$ & $1.029^{\mathrm{A}, \mathrm{B}}$ & $-0.538^{b}$ \\
\hline E & 2.9 & $3.5^{\mathrm{b}}$ & $8.5^{\mathrm{a}}$ & $16.0^{\mathrm{a}, \mathrm{b}}$ & $1.030^{\mathrm{A}}$ & $-0.537^{b}$ \\
\hline $\mathrm{BMT}^{* * * *}$ & 2.8 & $3.2^{\mathrm{b}}$ & $8.5^{\mathrm{b}, \mathrm{c}}$ & $16.3^{\mathrm{a}}$ & $1.030^{\mathrm{A}, \mathrm{B}}$ & $-0.538^{b}$ \\
\hline
\end{tabular}

${ }^{*}$ Different lower-case letters in the same column indicates significant differences by the Tukey test $(\mathrm{P}<0.05)$. Different upper-case letters in the same column indicate significant differences by the Tukey test $(\mathrm{P}<0.10){ }^{* *} \mathrm{NFS}=$ non-fat solids; ${ }^{* * *}$ Density was determined at $15^{\circ} \mathrm{C}$; ${ }^{* * *} \mathrm{BMT}=$ bulk milk transportation. Minimum values: crude protein $(2.9 \%)$, fat $(3 \%)$, NFS $(8.4 \%)$, density $\left(1.028-1.034 \mathrm{~g} \mathrm{~mL} \mathrm{~m}^{-1}\right)$, cryoscopy index (from -0.530 to $-0.550^{\circ} \mathrm{H}$ ).

to the good practices adopted in that farm (Table 1). Some studies report off-flavor in dairy products when raw milk TBC is over $10^{6} \mathrm{CFU} \mathrm{mL}^{-1}$ (MUIR, 1996; SANTOS et al., 2009). High percentage of psychrotrophic bacteria indicates poor hygiene during milking and/or faulty procedures during storage and transportation of cooled milk. In proper sanitary conditions, psychrotrophic count is lower than $10 \%$ of the total microbiota in raw milk. However, the psychrotrophic microorganisms rate can exceed $75 \%$ when handling is faulty (SUHREN, 1989).

Pseudomonas spp. average count in milk from dairy farms ranged from $2.3 \times 10^{5}$ to $1.7 \times 10^{6} \mathrm{CFU}$ $\mathrm{mL}^{-1}$ (Table 3). P. fluorescens average count ranged from $6.2 \times 10^{2}$ to $8.4 \times 10^{4} \mathrm{CFU} \mathrm{mL}^{-1}$. Similar findings were also reported in milk from dairy farms where good milking practices have not been implemented $\left(1.6 \times 10^{5} \mathrm{CFU}\right.$ $\mathrm{mL}^{-1}$ of Pseudomonas spp.), and poor water quality is pointed as the key factor for the high bacterial count (FAGUNDES et al., 2006). Pseudomonas spp. average count in milk dairy farm $\mathrm{E}$ was lower $(\mathrm{P}<0.05)$ than in the BMT reported in the five dairy farms studied. According to FAGUNDES et al. (2006), the average count of Pseudomonas spp. in milk from dairy farms with poor hygiene handling is higher than in those where milking practices are appropriate.

Pseudomonas spp. are the Gram negative species most commonly reported in cooled raw milk (JAYARAO \& WANG, 1999; FAGUNDES et al., 2006; ARCURI et al., 2008). However, this was not observed in this study (Table 4). Pseudomonas

Table 3 - Average bacterial count $\left(\mathrm{CFU} \mathrm{mL} \mathrm{m}^{-1}\right)$ in raw milk samples from individual refrigerated cooling tanks of five milk farms (A, B, C, D, and E) and the bulk milk transportation (BMT) before delivery to a dairy industry in the region of Londrina, Paraná State, Brazil, from June 2013 to February 2014

\begin{tabular}{|c|c|c|c|c|c|c|}
\hline A & $\mathrm{B}$ & $\mathrm{C}$ & $\mathrm{D}$ & $\mathrm{E}$ & Mean counts ${ }^{\dagger}$ & BMT $^{*}$ \\
\hline 3.1 & 4.0 & 3.3 & 3.4 & 3.3 & 3.4 & 6.6 \\
\hline \multicolumn{7}{|c|}{ 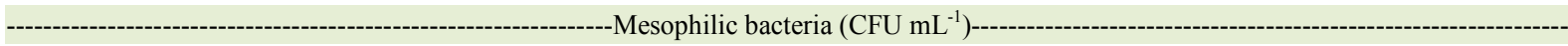 } \\
\hline $1.6 \times 10^{6 \mathrm{a}, \mathrm{b}}$ & $3.7 \times 10^{6 \mathrm{a}}$ & $3.5 \times 10^{6 \mathrm{a}, \mathrm{b}}$ & $8.4 \times 10^{5 b}$ & $3.4 \times 10^{5 b}$ & $2.0 \times 10^{6 \mathrm{~A}}$ & $1.4 \times 10^{6 \mathrm{a}, \mathrm{b}, \mathrm{A}}$ \\
\hline \multicolumn{7}{|c|}{ 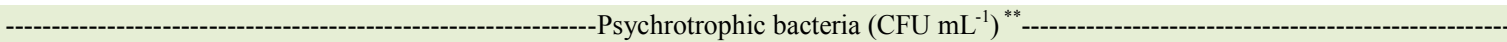 } \\
\hline $1.68 \times 10^{6 \mathrm{a}}$ & $9.5 \times 10^{6 \mathrm{a}}$ & $3.1 \times 10^{7 \mathrm{a}}$ & $1.5 \times 10^{6 \mathrm{a}, \mathrm{b}}$ & $4.0 \times 10^{5 \mathrm{~b}}$ & $8.9 \times 10^{6 \mathrm{~A}}$ & $2.8 \times 10^{6 \mathrm{a}, \mathrm{A}}$ \\
\hline \multicolumn{7}{|c|}{ - } \\
\hline $6.6 \times 10^{5}$ a & $1.8 \times 10^{6 \mathrm{a}}$ & $1.7 \times 10^{6 \mathrm{a}, \mathrm{b}}$ & $2.3 \times 10^{5 \mathrm{a}, \mathrm{b}}$ & $2.5 \times 10^{5 b}$ & $9.3 \times 10^{5 \mathrm{~A}}$ & $5.1 \times 10^{5 \mathrm{a}, \mathrm{A}}$ \\
\hline \multicolumn{7}{|c|}{ 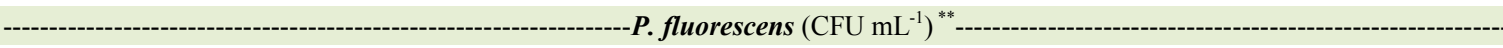 } \\
\hline $6.0 \times 10^{3 \mathrm{a}}$ & $8.4 \times 10^{4 \mathrm{a}}$ & $6.2 \times 10^{2 \mathrm{a}}$ & $3.3 \times 10^{3 \mathrm{a}}$ & $1.4 \times 10^{3 \mathrm{a}}$ & $1.9 \times 10^{4 \mathrm{~A}}$ & $1.7 \times 10^{4 \mathrm{a}, \mathrm{A}}$ \\
\hline
\end{tabular}

${ }^{*} \mathrm{BMT}=$ bulk milk transportation ${ }^{* *}$ Different lower-case letters in the same row indicate significant difference by the Tukey test $(\mathrm{P}<0.05)$. Identical upper-case letters in the same line indicate non-significant difference $(\mathrm{P}>0.05){ }^{\dagger}$ Mean counts in milk from dairy farms. 
Table 4 - Percent ratios of microorganisms reported in raw milk samples collected in cooling tanks of five milk farms (A, B, C, D, and E) and bulk milk transportation (BMT) to a dairy industry in the region of Londrina, Paraná State, Brazil, from June 2013 to February 2014.

\begin{tabular}{lcr}
\hline Milk farms & Pseudomonas spp. / Psychrotrophic (\%) & P. fluorescens / Pseudomonas spp. (\%) \\
\hline A & 41.84 & 0.91 \\
B & 18.74 & 4.73 \\
C & 5.40 & 0.04 \\
D & 15.20 & 1.42 \\
E & 62.47 & 0.56 \\
BMT $^{*}$ & 17.93 & 3.42 \\
\hline
\end{tabular}

${ }^{*} \mathrm{BMT}=$ bulk milk transportation.

spp. count was $17.9 \%$ of the entire psychrotrophic population, whereas $\boldsymbol{P}$. fluorescens was $3.4 \%$ of the Pseudomonas spp. population (Table 4) in the BMT milk delivered to the dairy industry. Another study conducted in Brazil (ARCURI et al., 2008) reported that in cooled raw milk Pseudomonas spp. count was $43 \%$ of the total psychrotrophic Gram negative strains, and $\boldsymbol{P}$. fluorescens was the most common specie $(37.6 \%)$, which was followed by $\boldsymbol{P}$. putida . Conversely, $\boldsymbol{P}$. fluorescens was the predominant species $(29.9 \%)$ in cooled raw milk in the USA (JAYARAO \& WANG, 1999). The time elapsed between sampling of cooled raw milk at the farms and its arrival to the dairy plant was $6 \mathrm{~h}$. However, the authors observed that milk remained in the bulk tank for up to $10 \mathrm{~h}$, was stored in the cooling tanks for more than $48 \mathrm{~h}$ on many occasions. It is well established that temperature and storage period are crucial, especially regarding psychotropic microorganisms, whose population increase over time even under refrigeration (NÖRNBERG et al., 2009; SANTOS et al., 2009). However, no difference $(\mathrm{P}>0.05)$ was observed between the milk average study populations in dairy farms and BMT arrival to the industry. Therefore, short-distance routes such the one studied here may not be determinant for overall milk bacterial count. However, initial milk microbiological status at dairy farms play an important role in the average bacterial count in milk delivered to dairy industry.

\section{CONCLUSION}

The genus Pseudomonas spp. and the species $\boldsymbol{P}$. fluorescens were not the most frequent psychrotrophic bacteria in cooled milk. Bulk milk transportation did not affect the population of mesophilic and psychrotrophic bacteria such as Pseudomonas spp. and Pseudomonas fluorescens in raw milk received by the dairy industry.

\section{REFERENCES}

ANDRADE, N.J. et al. Growth and adherence on stainless steel by Enterococcus faecium cells. Journal of Food Protection, v.61, p.1454-1458, 1998. Available from: <http://www.ncbi.nlm.nih. gov/pubmed/9829184> . Accessed: Jan, 2015. doi: 10.1111/j.15746968.2002.tb11446.x.

AOAC (ASSOCIATION OF OFFICIAL ANALYTICAL CHEMISTS). Official Methods of Analysis of Association of Official Analytical chemists. 16 ed. Gaithersburg, 1997. 1141p.

ARCURI, E.F. et al. Counting, isolation and characterization of psychrotrophic bacteria from refrigerated raw milk. Ciência Rural, v.38, p.2250-2255, 2008. Available from: $<$ http://www. scielo.br/pdf/cr/v38n8/a25v38n8.pdf>. Accessed: Nov. 11, 2015. doi: $10.1590 / \mathrm{S} 0103-84782008000800025$.

BRAMLEY, A.J.; MCKINNON, C.H. The microbiology of raw milk. In: ROBINSON, R.K. (Ed.). Dairy microbiology. New York: Elsevier Applied Science Publishers, 1996. p.163-208.

BRASIL. Ministério da Agricultura, Pecuária e Abastecimento: Instrução Normativa 51 de 18 de setembro de 2002. Regulamento Técnico de Produção, Identidade e Qualidade de Leite Tipo A, Tipo B, Tipo C e Cru refrigerado. Diário Oficial [da República Federativa do Brasil], Brasília, 29 set. 2002. Seção 1, p.13.

BRASIL. Ministério da Agricultura, Pecuária e Abastecimento: Instrução Normativa 62, de 29 de Dezembro de 2011. Aprova o Regulamento Técnico de Produção, Identidade e Qualidade do Leite tipo A, o Regulamento Técnico de Identidade e Qualidade de Leite Cru Refrigerado, o Regulamento Técnico de Identidade e Qualidade de Leite Pasteurizado e o Regulamento Técnico da Coleta de Leite Cru Refrigerado e seu Transporte a Granel. Diário Oficial [da República Federativa do Brasil], Brasília, 30 dez. 2011. Seção 1, p. 6.

CATANIO, F.S. et al. Raw milk quality of a processing plant in the north of Parana after the implementation of changes imposed by NI 62 of 2011. Semina: Ciências Agrárias, v.33, p.3171-3180, 2012. Available from: $<$ http://www.uel.br/revistas/uel/index.php/ semagrarias/article/view/13682/11965>. Accessed: May 16, 2016. doi: 10.5433/1679-0359.2012v33n6Supl2p3171.

FAGUNDES, C.M. et al. Presence of Pseudomonas spp. in milking phases with different hygienic handling procedures and in refrigerated milk. Ciência Rural, v.36, p.568-572, 2006. Available from: <http://www.scielo.br/pdf/cr/v36n2/ 
a32v36n2.pdf $>$. Accessed: Nov. 11, 2015. doi: 10.1590/S010384782006000200032 .

HOUGHTBY, G.A. et al. Microbiological count methods. In: MARSHALL, R.T. (Ed.). Standard methods for the examination of dairy products. New York: American Public Health Association, 1992. p.213-244.

JAYARAO B.M.; WANG LA. Study on the prevalence of Gram negative bacteria in bulk tank milk. Journal of Dairy Science, v.82, p.2620-2624, 1999. Available from: $<$ http://www. journalofdairyscience.org/article/S0022-0302(99)75518-9/pdf $>$. Accessed: Nov. 11, 2015. doi: 10.3168/jds.S0022-0302(99)75518-9.

KING, E.O et al. Two simple media for the demonstration of pyocyanin and fluorescein. Journal of Laboratory and Clinical Medicine, v.44, n.2, p.301-307, 1954. Available from: <http://www. ncbi.nlm.nih.gov/pubmed/13184240>. Accessed: Nov 11, 2015.

MARTINS, P.R.G. et al. Milk production and quality at the dairy region of Pelotas, Rio Grande do Sul State at different months of the year. Ciência Rural, v.36, p.209-214, 2006. Available from: $<$ http://www.scielo.br/pdf/cr/v36n1/a32v36n1.pdf $>$. Accessed: Nov. 11, 2015. doi: 10.1590/S0103-84782006000100032.

MARTINS, M.E.P. et al. Qualidade de leite cru produzido e armazenado em tanques de expansão no estado de Goiás. Ciência Animal Brasileira, v.9, p.1152-1158, 2008. Available from: $<\mathrm{http}: / /$ revistas. bvs-vet.org.br/cab/article/view/5136>. Accessed: Mar. 17, 2016.

MUIR, D.D. The shelf-life of dairy products: 1. Factors influencing raw milk and fresh products. Journal of the Society of Dairy Technology, v.49, p.24-32, 1996. Available from: <http://onlinelibrary.wiley.com/ doi/10.1111/j.1471-0307.1996.tb02616.x/pdf >. Accessed: Nov. 11, 2015. doi: 10.1111/j.1471-0307.1996.tb02616.x.

NORNBERG, M.F.B.L. et al. Psychrotrophic bacteria and proteolytic activity in refrigerated raw milk. Acta Scientiae Veterinariae, v.37, p.157-163, 2009. Available from: <http:// www.ufrgs.br/actavet/37-2/art825.pdf>. Accessed: Nov. 11, 2015.

OLIVEIRA, J.S.; PARMELEE, C.E. Rapid enumeration of psychrotrophic bacteria in raw and pasteurized milk. Journal of Milk and Food Technology, v.39, p.269-272, 1976.
RIBEIRO JUNIOR, J.C. et al. Quality of milk produced by small and large dairy producers. Semina: Ciências Agrárias, v.36, p.883-888, 2015. Available from: <http:// www.uel.br/revistas/uel/index.php/semagrarias/article/ view/19745/16125>. Accessed: Mar. 17, 2016. Doi: $10.5433 / 1679-0359.2015 \mathrm{v} 36 \mathrm{n} 2 \mathrm{p} 883$.

SANTOS, P.A. et al. Effect of time and temperature of refrigeration in the development of psychrotrophic microrganisms in cooled raw milk collected in the macroregion of Goiania. Ciência Animal Brasileira, v.10, p.1237-1245, 2009. Available from: <http:// www.revistas.ufg.br/index.php/vet/rt/printerFriendly/3522/6037>. Accessed: Nov. 11, 2015.

SILVA, L.C.C. et al. Tracking sources of microbiologic contamination of raw milk during milking process in dairy farms from Agreste of Pernambuco. Semina: Ciências Agrárias, v.32, p.267-276, 2011. Available from: <http://www.uel.br/revistas/uel/ index.php/semagrarias/article/view/3279/7193>. Accessed: Nov. 11, 2015. doi: 10.5433/1679-0359.2011v32n1p267.

SUHREN, G. Producer microorganisms. In: MCKELLAR, R.C. (Ed.). Enzymes of psychrotrophs in raw foods. Boca Raton: CRC, 1989. p.3-34

STATSOFT, Inc. STATISTICA 8.0 for Windows [Data analysis software system]. Tulsa, 2008. 298p.

VALLIN, V.M. et al. Milk quality improvement after implantation of good manufacturing practices in milking in 19 cities of the central region of Paraná. Semina: Ciências Agrárias, v.30, p.181-188, 2009. Available from: $<$ http://www.uel.br/revistas/uel/index.php/semagrarias/ article/view/2661/2313>. Accessed: Nov. 17, 2015. doi: 10.5433/1679-0359.2009v30n1p181.

WALSTRA, P. et al. Dairy science and technology. 2.ed. New York: Marcel Dekker, 2006. 727p.

YAMAZI, A.K. et al. Producing practices applied on the control of microbiological contamination in raw milk. Bioscience Journal, v.26, p.610-618, 2010. Available from: <http://www.seer.ufu.br/ index.php/biosciencejournal/article/view/7210/5136>. Accessed: Nov. 17, 2015. 